\title{
Multienzyme Modification of Hemp Protein for Functional Peptides Synthesis
}

\author{
Ranjana Das \\ Chemical Engineering Department, Jadavpur University, Kolkata 700032, India \\ Correspondence should be addressed to Ranjana Das; ranjanads78@gmail.com
}

Received 31 August 2015; Revised 2 November 2015; Accepted 11 November 2015

Academic Editor: Subramaniam Sathivel

Copyright (C) 2015 Ranjana Das. This is an open access article distributed under the Creative Commons Attribution License, which permits unrestricted use, distribution, and reproduction in any medium, provided the original work is properly cited.

\begin{abstract}
Functional foods and nutraceuticals are of special importance, particularly for their impact on human health and prevention of certain chronic diseases. Consequently, the production and properties of bioactive peptides have received an increasing scientific interest over past few years. Present work intends to compare the competence of metalloendopeptidases ("Protease N" and "Protease A") with papain for getting functional peptides from hemp seed meal, which is an obligatory waste of hemp fiber production industry. As a measure of the functional potential hemp protein hydrolysates were analyzed for their antiradical properties in DPPH system. "Protease N" modified protein hydrolysate exhibited comparatively superior radical scavenging activity in DPPH system. Overall findings represent the importance of "Protease N," as endopeptidase in getting peptides of good antiradical properties from various protein sources.
\end{abstract}

\section{Introduction}

Hemp, Cannabis sativa L., is a member of the hemp family Cannabaceae. C. sativa L., commonly referred to as hemp, is a widely cultivated plant of industrial importance, like food, fiber, and medicines. Historically hemp has been used primarily for the fiber cultigens and fiber preparations. $C$. sativa was most valued as a fiber source and only to a limited extent as an oilseed crop. Hemp, grown under license mostly in Canada, is the most publicized "new" crop of immense nutritional prospect. In March 1998, new regulations (under the Controlled Drugs and Substances Act) were provided to allow the commercial development of a hemp industry in Canada. Some articles have publicized hemp as "the new billion dollar crop," stating that it "can be used to produce more than 25,000 products, ranging from dynamite to Cellophane." Because of the lacking of extensive researches in the field of the hemp seed utilization practices, this study emphasize the production of hemp seed based value added components. Hemp has high levels of vitamins A, C, and $\mathrm{E}$ and beta-carotene, and it has been reported as rich source of protein $(25 \%)$, carbohydrates, minerals, and fiber $[1,2]$. Hemp seed protein has been reported to have higher level of sulphur containing amino acids, with methionine content much higher than in soy bean protein isolate $[1,3]$. Hemp seed has been confirmed as an excellent source of nutrition when fed to laying hens $[4,5]$ and pigeons [6]. The hemp protein fractions (mainly edestin and albumin) in hempseed have well-balanced amino acid compositions and easy digestibility [1]. From the seed, a methionine-and cystine-rich seed protein (10-kDa protein) has been isolated and identified [7]. In the hemp protein isolate (HPI), the edestin accounts for $80 \%$ of total hemp protein content [3]. Osborne $[8,9]$ reported the utility of globulin protein (edestin and edestan) from hempseed. The physicochemical and functional properties (especially protein solubility) of hemp protein isolate (HPI) are reported to be poorer in comparison to soy protein isolate (SPI) [3]. Although HPI has good potential to be applied as a source of protein nutrition, it shows much poorer functional properties, especially protein solubility, as compared to soy protein isolate (SPI) [3]. The poor functional properties might greatly limit the application of this protein in many food formulations. Many physical, chemical, and enzymatic treatments have been widely applied to modify the functional properties of plant proteins, with modification of protein structure $[10,11]$. Studies have also 
TABLE 1: Proximate analysis of hemp seed.

\begin{tabular}{lc}
\hline Parameters & Percent content \\
\hline Moisture & $2.83 \pm 0.20$ \\
Carbohydrate & $29.20 \pm 0.10$ \\
Protein & $24.00 \pm 0.40$ \\
Oil & $32.60 \pm 0.10$ \\
Ash & $4.65 \pm 0.30$ \\
Fiber & $17.80 \pm 0.20$ \\
\hline
\end{tabular}

been carried out in search of potent bioactive peptides from a variety of inexpensive sources [12-14]. Usually, the enzymatic modification is more preferable due to milder process conditions required, easier control of the reaction, and minimal formation of by-products $[15,16]$. In most modification processes, enzymatic hydrolysis has been most widely used to improve the functional properties of proteins, such as solubility, emulsification gelation, water and fatholding capacities, and foaming ability, or to tailor the functionality of certain proteins to meet specific needs [1719]. The aim of the present study is to produce hemp protein hydrolysate using a novel type membrane bioreactor with immobilized enzyme system to add value to the hemp meal and to improve the functionality hemp protein isolate.

\section{Material and Methods}

2.1. Materials. Authentic low tetrahydrocannabinol (THC) containing hemp seeds were purchased from Granny Organics, Dehradun, with specification as presented in Table 1. $\alpha, \alpha^{\prime}$-Diphenyl-1-picrylhydrazyl (DPPH) and 2,2' -azinobis (3-ethylbenzothiazoline-6-sulfonic acid) diammonium salt (ABTS) were purchased from Sigma Aldrich Chemical Co., USA. "Protease N Amano G" and "Protease A Amano 2G" enzymes were kind gift from Amano enzyme Inc. Nagoa Japan. Specificity of all these food grade enzymes is illustrated in Table 2. The membrane bioreactor used for synthesis of the protein hydrolysate is mentioned in our previous study [20]. The module is a dead end module with volume $500 \mathrm{~mL}$ with enzyme immobilized on the membrane surface. The enzyme used in the study is a metalloendopeptidase which was a kind gift from Nagoa Japan. All other chemicals, except otherwise stated, were purchased from E. Merck, India.

\subsection{Preparation of Protein Isolate from Hemp Seed and} Determination of Protein Content. Cold extracted hemp meal $(\mathrm{HM})$ was prepared using hexane at $24 \pm 1^{\circ} \mathrm{C}$. Hemp protein isolate (HPI) was obtained from defatted hemp meal by isoelectric point precipitation [3]. HPI was used as the substrate for carrying out enzymatic hydrolysis process. Defatted hemp meal was mixed with 20 -fold (w/v) deionized water at $30 \pm 1^{\circ} \mathrm{C}$, and the mixture was adjusted to $\mathrm{pH} 9.0$ with $1 \mathrm{~N} \mathrm{NaOH}$ and stirred for $1 \mathrm{~h}$. Samples were centrifuged at $10000 \times \mathrm{g}$ for $20 \mathrm{~min}$ at $25^{\circ} \mathrm{C}$. The supernatant was adjusted to $\mathrm{pH} 4.9$ with $1 \mathrm{~N} \mathrm{HCl}$, and the precipitate was collected by centrifugation $(10000 \times \mathrm{g}, 10 \mathrm{~min})$. The suspension was freeze-dried to produce HPI. Soluble protein content of hemp protein isolate (HPI) was measured following standard method of Lowry et al. [21], using bovine serum albumin (BSA) as standard at $750 \mathrm{~nm}$.

2.3. Preparation of Protein Hydrolysate, Evaluation of Degree of Hydrolysis, and Mass Distribution of Hydrolysates. Precipitated protein isolate was dissolved in DI water $(1: 20 \mathrm{w} / \mathrm{v})$ and $\mathrm{pH}$ adjusted according to the specificity of the enzyme used with constant stirring to achieve desired degree of hydrolysis. To the homogeneous solution of the protein isolate, enzymes were added with varying enzyme to substrate ratio of 1/1000 to $1 / 50$, and hydrolysis was carried out at $35 \pm 2{ }^{\circ} \mathrm{C}$ for $3 \mathrm{~h}$. Hydrolysate was readily immersed in boiling water bath $\left(95^{\circ} \mathrm{C}\right)$ for $1 \mathrm{~min}$ to inactivate the enzyme action. The solution was then stored at $4^{\circ} \mathrm{C}$ for further analysis.

In membrane bioreactor, the enzymes were immobilized on polyether sulfone membrane $(5000 \mathrm{Da})$ surface using glutaraldehyde according to the techniques of Jasim et al. 1987 [22]. Immobilization was done with 10\% glutaraldehyde in chilled phosphate buffer $(0.05 \mathrm{M}, \mathrm{pH}$ 6.5). The design of the bioreactor is available elsewhere [23]. The reaction was continued in total recycle mode for $3 \mathrm{~h}$ to achieve desired degree of hydrolysis. After $3 \mathrm{~h}$, permeate was collected and stored for further analysis at $4^{\circ} \mathrm{C}$. No enzyme inactivation was done in this mode as enzyme system was immobilized on membrane surface and having high molecular weight.

Degree of hydrolysis was determined according to the method of Alder-Nissen, 1979 using 2,4,6-trinitrobenzene sulphonic acid [24]. Sample solution $(0.25 \mathrm{~mL})$ is mixed in a test tube with $2.0 \mathrm{~mL}$ of phosphate buffer at $\mathrm{pH}-8.2$. $2 \mathrm{~mL}$ of TNBS solution which was added and the test tube was shaken and placed in a water bath at $50^{\circ} \mathrm{C}$ for $60 \mathrm{~min}$. During incubation, test tubes and the water bath maintained covered with aluminum foil as the blank reaction may be accelerated by exposure to light. After 60 minutes $4.0 \mathrm{~mL}$ of $0.1(\mathrm{~N}) \mathrm{HCl}$ was added to terminate the reaction, and the test tube was allowed to stand at room temperature for $30 \mathrm{~min}$ before the absorbance was read against water at $340 \mathrm{~nm}$. Total number of amino groups were determined in a sample of $100 \%$ hydrolysate at $110^{\circ} \mathrm{C}$ or $24 \mathrm{~h}$ in $6(\mathrm{~N}) \mathrm{HCl}(10 \mathrm{mg}$ sample in $4 \mathrm{~mL} \mathrm{HCl}$ ). The ratio of the number of amino acids in hydrolysate to total amino acid content is used as the measure of the degree of hydrolysis. The molecular weight distributions of protein hydrolysate and different peptide fractions were analyzed in RP-HPLC system (Cyber Lab, Millbury, USA) with "Phenomenex C18" column, $(4.6 \times 250 \mathrm{~mm}, 5 \mu \mathrm{m})$ at $25^{\circ} \mathrm{C}$. Peptides were eluted at flow rate of $1 \mathrm{~mL} /$ minute with various gradient mixtures composed of solvent $\mathrm{A}$ (water with $1 \%$ acetonitrile and $0.01 \%$ trifluoroacetic acid) and solvent $\mathrm{B}$ (acetonitrile with $0.01 \%$ trifluoroacetic acid). The gradient elution condition was maintained as $100 \%$ solvent A for 5 minutes, $0-30 \%$ solvent $\mathrm{B}$ for 15 minutes, $30-50 \%$ solvent B for 25 minutes, and 50-100\% solvent B for 35 minutes. Elution profile was monitored at $220 \mathrm{~nm}$. Mass analysis of peptide fractions was done in Quadrupole-TOF Micromass Spectrometer (Water, USA).

2.4. Radical Scavenging Activity (RSA) of Protein Hydrolysates. RSA of hemp peptide fractions were evaluated in DPPH 
TABLE 2: Specificity of the enzyme system (papain, Protease N Amano G, and Protease A Amano 2G) used for hydrolysis of hemp protein.

\begin{tabular}{|c|c|c|c|c|}
\hline Enzyme & Source & Nature & Optimum temperature/pH & Activity \\
\hline $\begin{array}{l}\text { Papain } \\
\text { (E.C. 3.4.22.2) }\end{array}$ & Papaya & Cysteine protease & $55-60^{\circ} \mathrm{C} / \mathrm{pH} 5-7$ & $10,000 \mathrm{U} / \mathrm{g}$ \\
\hline $\begin{array}{l}\text { Protease } \mathrm{N} \\
\text { Amano G } \\
\text { (E.C. } 3.4 .24 .28) \\
\end{array}$ & Bacillus subtilis & Metalloendopeptidase & $55^{\circ} \mathrm{C} / \mathrm{pH} 7.5$ & $>150,000 \mathrm{U} / \mathrm{g}$ \\
\hline $\begin{array}{l}\text { Protease A } \\
\text { Amano } 2 \mathrm{G} \\
\text { (E.C. } 3.4 .24 .39)\end{array}$ & Aspergillus oryzae & Metalloendopeptidase & $50^{\circ} \mathrm{C} / \mathrm{pH} 7.0$ & $20,000 \mathrm{U} / \mathrm{g}$ \\
\hline
\end{tabular}

TABLE 3: Yield of hemp protein isolate (w/w; dry basis) and characteristics.

\begin{tabular}{lc}
\hline Parameters & HPI \\
\hline Yield of HPI\% & $76.7 \pm 0.10$ \\
Protein content \% & $86.4 \pm 0.12$ \\
Fiber \% & $3.4 \pm 0.22$ \\
Ash \% & $5.6 \pm 0.10$ \\
\hline
\end{tabular}

Results are presented as mean \pm SEM, $n=3$.

system. DPPH-radical scavenging activity of peptides was determined using the method of Yen and $\mathrm{Wu}, 1999$ [25]. Radical scavenging activity of the hydrolysates/peptide fractions were expressed as concentration $(\mathrm{mg} / \mathrm{L})$ required for scavenging half of the free radical concentration in the reaction system $\left(\mathrm{IC}_{50}\right)$. Nonpeptidic antioxidants tocopherol and tertiary butyl hydroquinone (TBHQ) were also tested for comparison, under the similar reaction condition.

2.5. Statistical Analysis. All results are expressed as mean \pm SEM (standard error of mean), of three determinations. Statistical analysis was done by analysis of variance (ANOVA). A value of $p<0.05$ was considered statistically significant. MATLAB 7.0 software was used for statistical analysis.

\section{Results and Discussion}

3.1. Characteristics of the Hemp Protein Isolate and Hydrolysate. Compositional analysis of HPI showed comparatively less ash and fiber content in protein isolate as illustrated in Table 3. Each protein isolate (1g) was subjected to controlled hydrolysis with three enzyme systems with varying enzyme to substrate ratio $(0.1-2 \mathrm{w} / \mathrm{w} \%)$, to get respective protein hydrolysates, which are considered as source of small peptides having diverse activity profile. Effect of enzyme to substrate ratio on degree of hydrolysis $(\mathrm{DH})$ of hemp protein isolate is illustrated in Table 4. For a specified enzyme to substrate ratio value "Protease N" showed better activity as compared to other two enzyme types. Similar observations were also observed for each enzyme concentration level. Analysis of variance shows that both "enzyme type" and "enzyme dose" have significant effect on DH ( $p=0.008)$, but there is no synergistic/interactive effect of these two parameters $(p=0.8771)$. Since our objective was to optimize the peptide population and their activity, so, enzyme dose

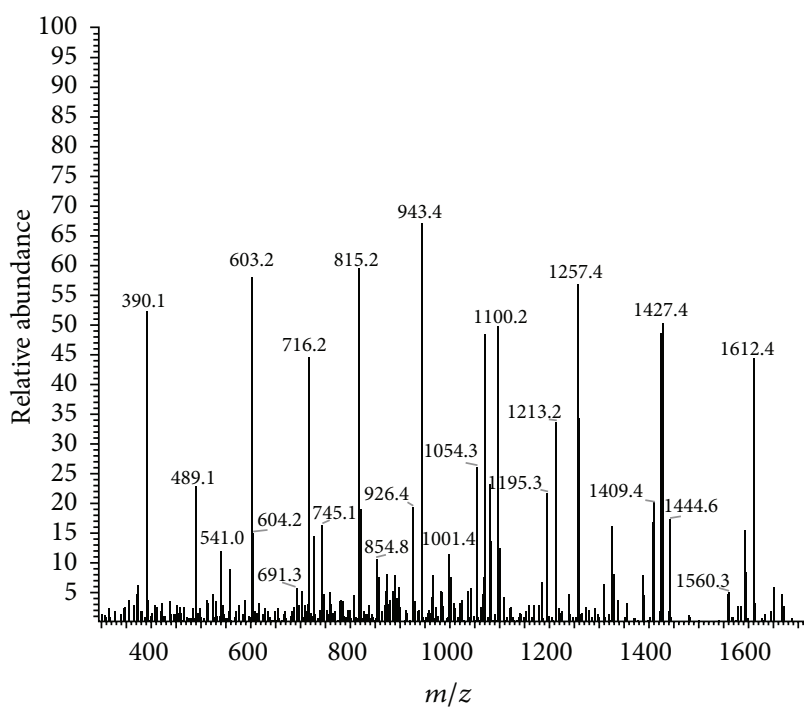

FIGURE 1: Molecular weight distribution of the hemp protein hydrolysate as obtained after $2 \mathrm{~h}$ of hydrolysis.

was limited to $2 \%$; further increase in enzyme quantity was found to lower the activity of protein hydrolysates, which may be due to formation of more free amino acids and too small peptides with insignificant activity. Further studies were done to evaluate the activity profile of all protein hydrolysates as DH cannot simply be correlated with activity of protein hydrolysates. Molecular weight distribution pattern for protein hydrolysate obtained after $2 \mathrm{~h}$ is presented in Figure 1. It represents the presence of several small peptides with molecular weight bellow $2000 \mathrm{Da}$ which are often characterized and evaluated as bioactive peptides in previous publications [1518].

\subsection{DPPH-Radical Scavenging Behavior of Hemp Protein} Hydrolysate. DPPH in methanol (absorption maxima at $517 \mathrm{~nm}$ ) is a very stable free radical system used to assay the radical scavenging activity and antioxidant potential. Free radicals in induced oxidation system propagate the oxidative chain reactions and enhance the rate of oxidation. Any components having the properties of scavenging those free radicals can serve the purpose of antioxidant. According to Shimada et al. [26] when DPPH radical encounters a protondonating substance, an antioxidant, the radical is scavenged 
TABLE 4: Effect of enzyme dose on degree of hydrolysis ${ }^{\mathrm{a}}$.

\begin{tabular}{lcccc}
\hline Source material & \% enzyme dose $(\mathrm{w} / \mathrm{w})$ & $\begin{array}{c}\text { Papain } \\
(\% \mathrm{DH})\end{array}$ & $\begin{array}{c}\text { Protease N Amano } \\
\text { G }(\% \mathrm{DH})\end{array}$ & $\begin{array}{c}\text { Protease A Amano } \\
2 \mathrm{G}(\% \mathrm{DH})\end{array}$ \\
\hline 0.1 & $24.7 \pm 0.70$ & $26.3 \pm 0.54$ & $25.4 \pm 0.03$ \\
& 0.5 & $28.6 \pm 0.10$ & $32.0 \pm 0.13$ & $28.9 \pm 0.21$ \\
HPI & 1.0 & $30.0 \pm 0.13$ & $33.0 \pm 0.21$ & $30.8 \pm 0.01$ \\
& 1.5 & $31.3 \pm 0.11$ & $33.9 \pm 0.09$ & $32.0 \pm 0.10$ \\
& 2.0 & $33.3 \pm 0.14$ & $35.4 \pm 0.43$ & $33.7 \pm 0.60$ \\
\hline
\end{tabular}

${ }^{\mathrm{a}}$ Results are presented as mean $\pm \mathrm{SEM}, n=3$.

TABLE 5: DPPH radical scavenging activity in comparison commercial antioxidants.

\begin{tabular}{|c|c|c|c|c|c|}
\hline Source material & Papain $\left(\mathrm{EC}_{50}\right)^{\mathrm{a}} \mathrm{mg} / \mathrm{mL}$ & $\begin{array}{c}\text { Protease } \mathrm{N}\left(\mathrm{EC}_{50}\right) \\
\mathrm{mg} / \mathrm{mL}\end{array}$ & $\begin{array}{c}\text { Protease A }\left(\mathrm{EC}_{50}\right) \\
\mathrm{mg} / \mathrm{mL}\end{array}$ & $\begin{array}{c}\text { Tocopherol }\left(\mathrm{EC}_{50}\right) \\
\mathrm{mg} / \mathrm{mL}\end{array}$ & $\begin{array}{c}\text { TBHQ }\left(\mathrm{EC}_{50}\right) \\
\mathrm{mg} / \mathrm{mL}\end{array}$ \\
\hline HPI & $2.51 \pm 0.05$ & $2.14 \pm 0.01$ & $2.13 \pm 0.01$ & $0.24 \pm 0.02$ & $0.21 \pm 0.01$ \\
\hline $\mathrm{HPH}$ & $1.32 \pm 0.03$ & $1.24 \pm 0.06$ & $1.26 \pm 0.02$ & - & - \\
\hline
\end{tabular}

${ }^{\mathrm{a}} \mathrm{EC}_{50}$ concentration required for $50 \%$ reduction of $\mathrm{DPPH}$ radical concentration.

and the absorbance is reduced. The free radical is converted to more stable product thereby terminating the radical chain reactions. In our observation, protein hydrolysates exhibit strong radical scavenging activity when compared with synthetic antioxidant TBHQ and natural antioxidant tocopherol for their $\mathrm{EC}_{50}$ values (Table 5). Radical scavenging activity of these enzyme modified protein hydrolysates found to vary significantly $(p<0.05)$ with type of enzymes and degree of hydrolysis. During hydrolysis a mixture of small peptides and free amino acids are produced depending on enzyme specificity, and antioxidative potential of those peptide mixtures and amino acids depends on the sizes and the nature of the amino acid residue at the side chain of generated peptides. Jun et al. [27] have also highlighted the dependence of antioxidant activity on protease nature and hydrolysis condition employed. "Protease N" modified protein hydrolysate $\left(\mathrm{P}_{\mathrm{N}}\right)$ exhibits maximum radical scavenging activity $(8.77 \%)$ compared to "Protease A" $\left(\mathrm{P}_{\mathrm{A}}-5.2 \%\right)$ and "papain" modified protein hydrolysate $\left(\mathrm{P}_{\mathrm{P}}-3.06 \%\right)$ under similar hydrolyzing conditions and specified DH. This difference may be due to the variation of the nature of small peptides produced and also on the molecular weight distribution of the peptides. For a specific type of enzyme, radical scavenging activity also varies significantly with dose and degree of hydrolysis (Figure 2). Maximum radical scavenging activity for all protein hydrolysates was observed around $30 \% \mathrm{DH}$; activity further reduces on increasing degree of hydrolysis to $30 \%$, for all enzyme types used in this study. Inverse corelation of the degree of hydrolysis with radical scavenging activity is may be due to the formation of free amino acid residue which exhibits comparatively lower radical scavenging properties as compared to short peptides.

\section{Conclusions}

This study aims to assay the activity of some commercial endoproteinase for production of protein hydrolysate as

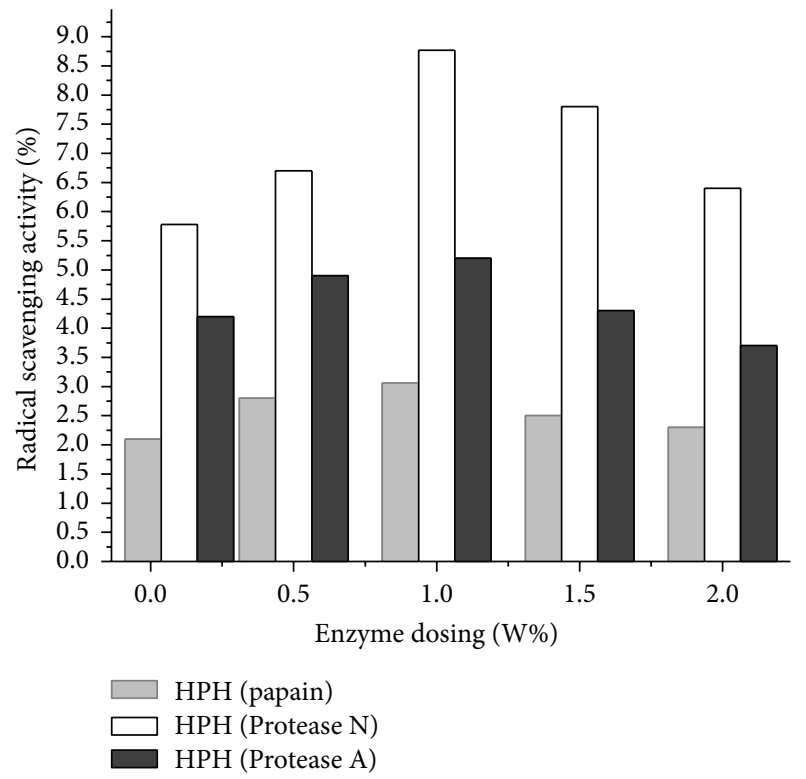

FIgURE 2: DPPH radical scavenging activity of "Protease A," "Protease $\mathrm{N}$," and "papain" modified protein hydrolysates as function of enzyme dosing.

source of bioactive peptides from hemp seed meal. Protein hydrolysates were analyzed for their radical scavenging potential in DPPH radical system. "Protease N" modified protein hydrolysate exhibited superior radical scavenging activity compared to others at $30 \%$ degree of hydrolysis and showed better radical scavenging activity. These findings also point to the relevance of metalloendopeptidase "Protease N" from Bacillus subtilis, as promising proteinase in preparing bioactive peptides from various protein sources. Results imply that these protein hydrolysates can serve as preservatives in improving the "self-life" of food emulsions as a radical scavenging agent. Characterization of these protein 
hydrolysates is beyond the scope of this study and hoped to be reported in our upcoming publications.

\section{Conflict of Interests}

The author declares that there is no conflict of interests regarding the publication of this paper.

\section{Acknowledgment}

The author would like to thank University Grant Commission (UGC) India, for providing fund as Dr. DS Kothari Postdoctoral Fellowship.

\section{References}

[1] J. C. Callaway, "Hempseed as a nutritional resource: an overview," Euphytica, vol. 140, no. 1-2, pp. 65-72, 2004.

[2] E. Small and D. Marcus, "Hemp: a new crop with new uses for North America," in Trends in New Crops and New Uses, pp. 284326, ASHS Press, Alexandria, Va, USA, 2002.

[3] C.-H. Tang, H. Wu, H.-P. Yu, L. Li, Z. Chen, and X.-Q. Yang, "Coagulation and gelation of soy protein isolates induced by microbial transglutaminase," Journal of Food Biochemistry, vol. 30, no. 1, pp. 35-55, 2006.

[4] M. Eriksson and H. Wall, "Hemp seed cake in organic broiler diets," Animal Feed Science and Technology, vol. 171, no. 2-4, pp. 205-213, 2012.

[5] F. G. Silversides and M. R. Lefrancois, "The effect of feeding hemp seed meal to laying hens," British Poultry Science, vol. 46, no. 2, pp. 231-235, 2005.

[6] I. Hullar, I. Meleg, S. Fekete, and R. Romvari, "Studies on the energy content of pigeon feeds I. determination of digestibility and metabolizable energy content," Poultry Science, vol. 78, no. 12, pp. 1757-1762, 1999.

[7] S. Odani and S. Odani, "Isolation and primary structure of a methionine- and cystine-rich seed protein of Cannabis sativa," Bioscience, Biotechnology and Biochemistry, vol. 62, no. 4, pp. 650-654, 1998.

[8] T. B. Osborne, "A hydrolytic derivative of the globulin edestin and its relation to Weyl's albuminate and the Histon group," Journal of the American Chemical Society, vol. 24, no. 1, pp. 2839, 1902 .

[9] T. B. Osborne, "The basic character of the protein molecule and the reactions of edestin with definite quantities of acids and alkalies," Journal of the American Chemical Society, vol. 24, no. 1, pp. 39-78, 1902.

[10] D. D. Kitts and K. Weiler, "Bioactive proteins and peptides from food sources, applications of bioprocesses used in isolation and recovery," Current Pharmaceutical Design, vol. 9, no. 16, pp. 1309-1323, 2003.

[11] R. Das, A. Dutta, and C. Bhattacharjee, "Preparation of sesame peptide and evaluation of antibacterial activity on typical pathogens," Food Chemistry, vol. 131, no. 4, pp. 1504-1509, 2012.

[12] R. C. Hider, "Honeybee venom: a rich source of pharmacologically active peptides," Endeavour, vol. 12, no. 2, pp. 60-65, 1988.

[13] F. Roy, J. I. Boye, and B. K. Simpson, "Bioactive proteins and peptides in pulse crops: pea, chickpea and lentil," Food Research International, vol. 43, no. 2, pp. 432-442, 2010.
[14] X. Tang, Z. He, Y. Dai, Y. L. Xiong, M. Xie, and J. Chen, "Peptide fractionation and free radical scavenging activity of zein hydrolysate," Journal of Agricultural and Food Chemistry, vol. 58, no. 1, pp. 587-593, 2010.

[15] C.-H. Tang, Z. Ten, X.-S. Wang, and X.-Q. Yang, "Physicochemical and functional properties of hemp (Cannabis sativa L.) protein isolate," Journal of Agricultural and Food Chemistry, vol. 54, no. 23, pp. 8945-8950, 2006.

[16] A. Mannheim and M. Cheryan, "Enzyme-modified proteins from corn gluten meal: preparation and functional properties," Journal of the American Oil Chemists Society, vol. 69, no. 12, pp. 1163-1169, 1992.

[17] A. Arzu, H. Mayorga, J. Gonzalez, and C. Rolz, "Enzymic hydrolysis of cottonseed protein," Journal of Agricultural and Food Chemistry, vol. 20, no. 4, pp. 805-809, 1972.

[18] S. Y. Kim, P. S.-W. Park, and K. C. Rhee, "Functional properties of proteolytic enzyme modified soy protein isolate," Journal of Agricultural and Food Chemistry, vol. 38, no. 3, pp. 651-656, 1990.

[19] C. A. Kuehler and C. M. Stine, "Effect of enzymatic hydrolysis on some functional properties of whey protein," Journal of Food Science, vol. 39, no. 2, pp. 379-382, 1974.

[20] R. Das, C. Bhattacherjee, and S. Ghosh, "Studies on membrane processing of sesame protein isolate and sesame protein hydrolysate using rotating disk module," Separation Science and Technology, vol. 44, no. 1, pp. 131-150, 2009.

[21] O. H. Lowry, N. J. Rosebrough, A. L. Farr, and R. J. Randall, "Protein measurement with the Folin phenol reagent," The Journal of Biological Chemistry, vol. 193, no. 1, pp. 265-275, 1951.

[22] M. A. Jasim, G. M. Hall, J. Mann, and K. D. A. Taylor, "A comparison of immobilised protease activities," Journal of Chemical Technology and Biotechnology, vol. 40, no. 4, pp. 251258, 1987.

[23] R. Das, D. Sen, A. Sarkar, S. Bhattacharyya, and C. Bhattacharjee, "A comparative study on the production of galactooligosaccharide from whey permeate in recycle membrane reactor and in enzymatic batch reactor," Industrial and Engineering Chemistry Research, vol. 50, no. 2, pp. 806-816, 2011.

[24] J. Adler-Nissen, "Determination of the degree of hydrolysis of food protein hydrolysates by trinitrobenzenesulfonic acid," Journal of Agricultural and Food Chemistry, vol. 27, no. 6, pp. 1256-1262, 1979 .

[25] G.-C. Yen and J.-Y. Wu, "Antioxidant and radical scavenging properties of extracts from Ganoderma tsugae," Food Chemistry, vol. 65, no. 3, pp. 375-379, 1999.

[26] K. Shimada, K. Fujikawa, K. Yahara, and T. Nakamura, "Antioxidative properties of xanthan on the autoxidation of soybean oil in cyclodextrin emulsion," Journal of Agricultural and Food Chemistry, vol. 40, no. 6, pp. 945-948, 1992.

[27] S.-Y. Jun, P.-J. Park, W.-K. Jung, and S.-K. Kim, "Purification and characterization of an antioxidative peptide from enzymatic hydrolysate of yellowfin sole (Limanda aspera) frame protein," European Food Research and Technology, vol. 219, no. 1, pp. 2026, 2004. 

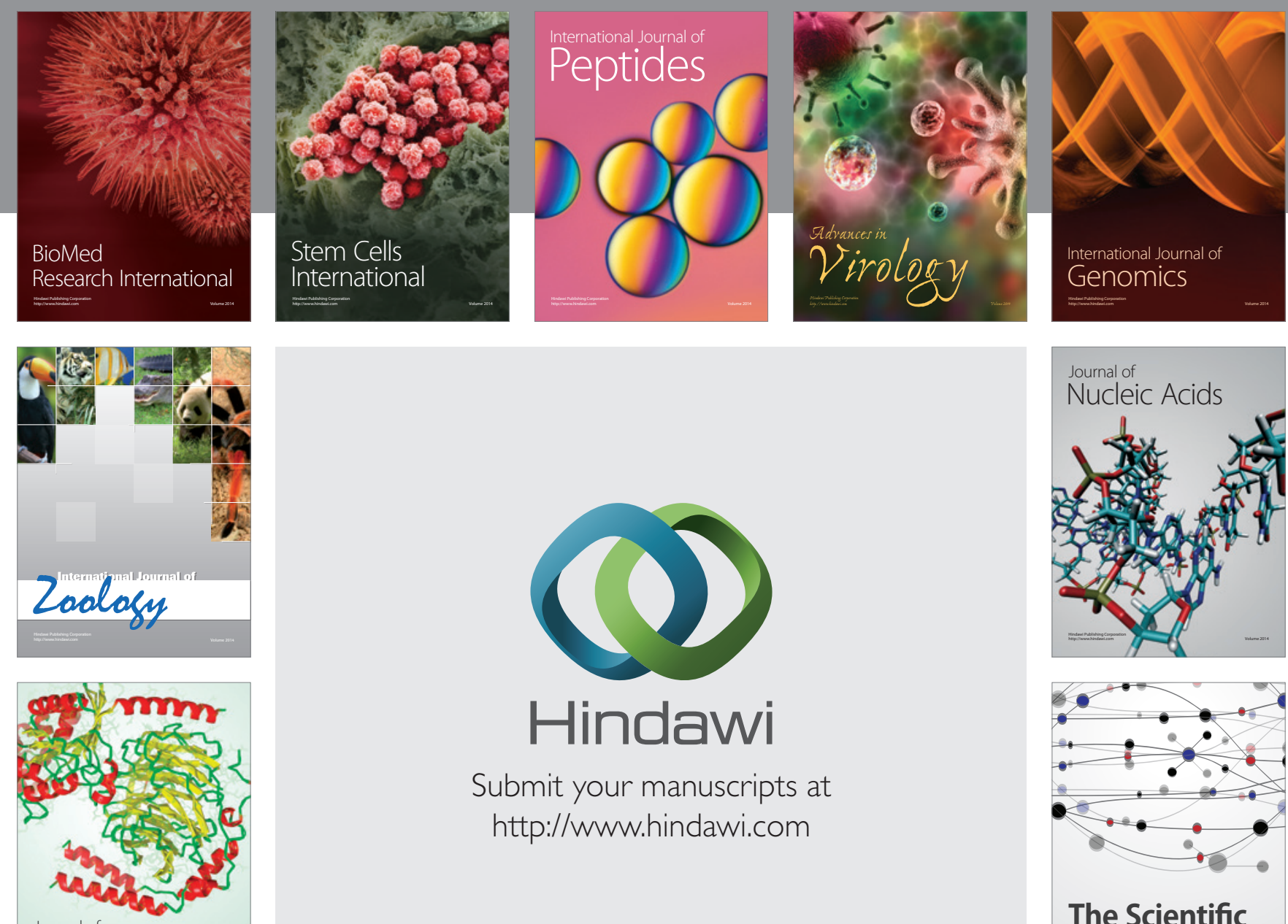

Submit your manuscripts at

http://www.hindawi.com

Journal of
Signal Transduction
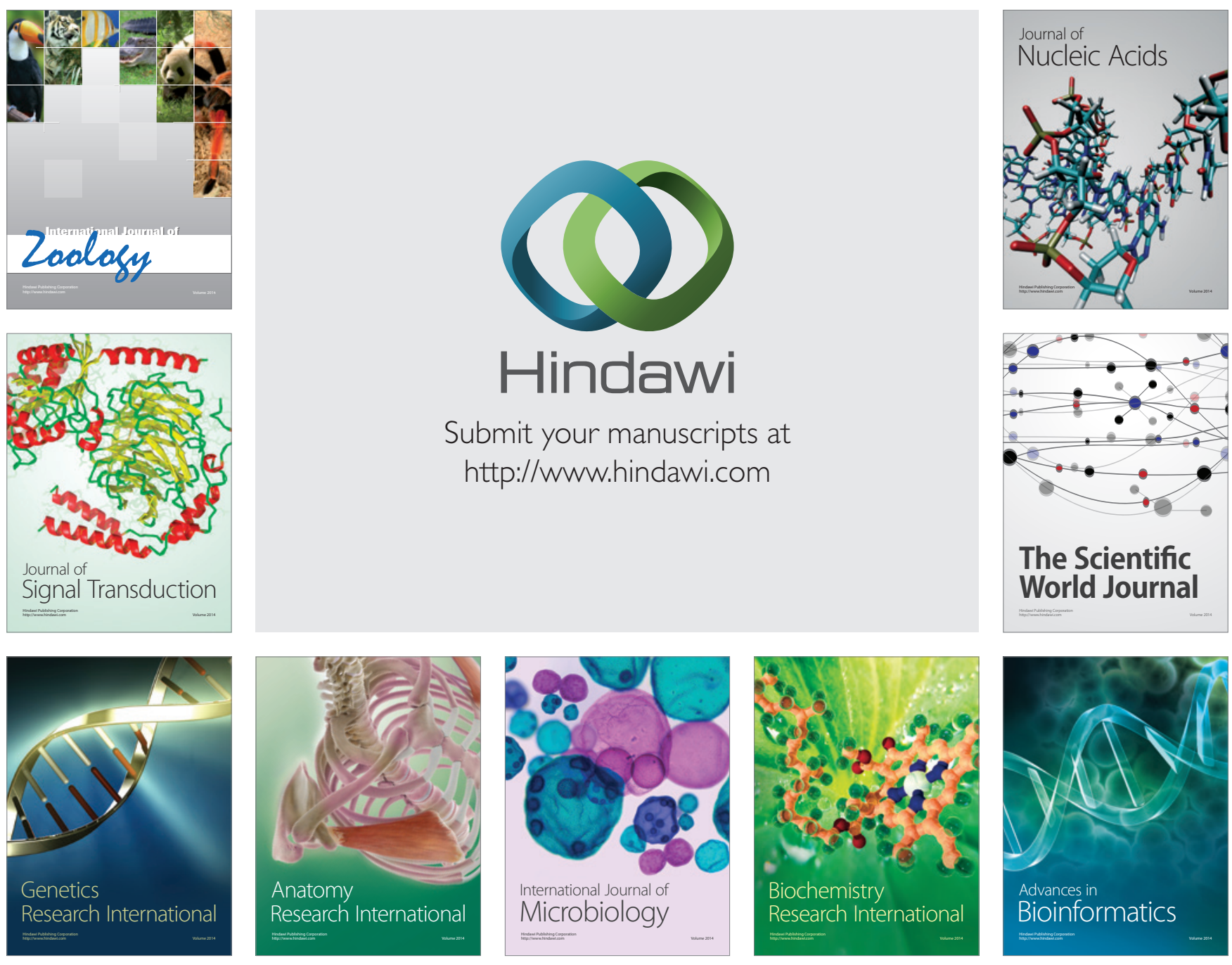

The Scientific World Journal
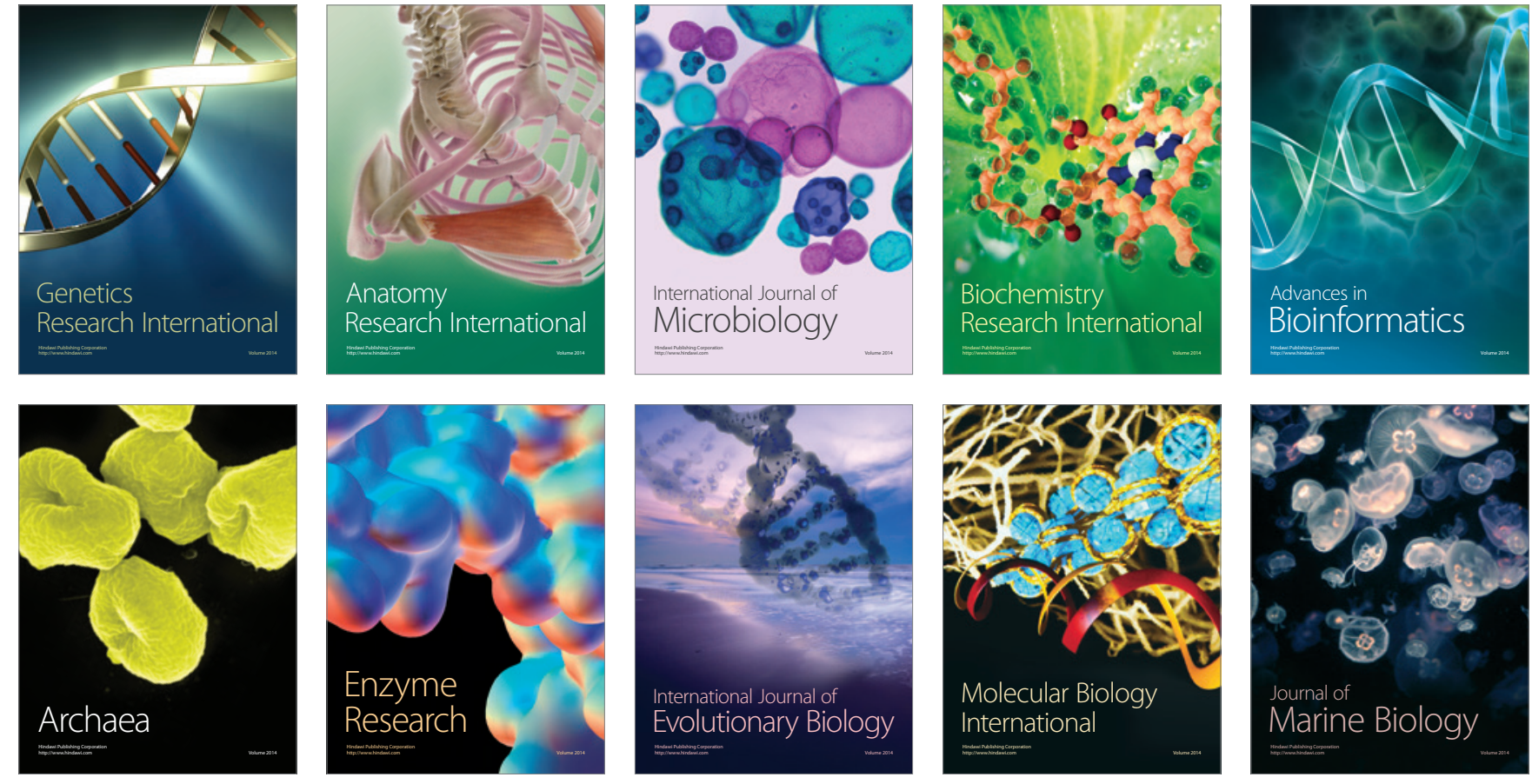